\title{
Seaweed Diversity and Conservation on the Warambadi Seashore of Sumba Island: Substrata and Seasonal Phenomenon
}

\section{Keragaman Jenis dan Konservasi Rumput Laut di Pantai Warambadi Pulau Sumba: Fenomena Substrat dan Musim}

\author{
JANA TJAHJANA ANGGADIREDJA \\ Technology Center for Territory Resource Development \\ The Agency for the Assessment and Application of Technology \\ Geostech Building (820), $2^{\text {nd }} \mathrm{fl}$, Puspiptek, Serpong 15314 \\ ina_seaweedsociety@yahoo.com
}

\begin{abstract}
The interaction between species and species diversity with their growing habitats are essential in the conservation of species. This study deals with the diversity and conservation of seaweed (marine macroalgae) with the emphasis on substrata habitats (sandy and rocky shores) and seasonal conditions (rainy and dry seasons). The study was carried out on the Warambadi seashore of Sumba Island. The t-test analysis showed that the "species diversity index of algae" $\left(H^{\prime}\right)$ on both sandy and rocky substrata did not significantly different. The $\left(H^{\prime}\right)$ during both rainy and dry seasons on different substratum (sandy and rocky substrata) did not show any significant differences. The two-way anova analysis recorded that the $\left(H^{\prime}\right)$ and the number of algae species were not affected by the differences of both substrata and seasons, but it was significantly affected by the interaction between the types of substratum and season. The study also reported that the types of substrata and seasons affected the $\left(H^{\prime}\right)$ of Chlorophyceae but not by of their interaction, and the ( $\left.H^{\prime}\right)$ of Rhodophyceae was affected by the types of substratum and season but not by their interaction. Moreover, the types of substratum and season affected the ( $\left.H^{\prime}\right)$ of Phaeophycea, but their interaction did not affect such diversity index. Substrata and seasonal phenomenon also indicate that the types of substratum, season, and their interactions affected the number of species Chlorophyceae, Rhodophyceae, and Phaeophyceae.
\end{abstract}

Keywords: seaweed, diversity, conservation, substrata, season

\begin{abstract}
ABSTRAK
Interaksi antara jenis dan keragaman jenis tumbuhan dengan habitat tempat tumbuhnya adalah hal yang mutlak diketahui dalam melakukan konservasi jenis tumbuhan. Studi ini berkenaan dengan keragaman jenis dan konservasi rumput laut (alga-makro laut) dengan penekanan perhatian pada habitat substrat (dasar laut berpasir dan berbatuan karang) serta kondisi cuaca (musim kemarau dan hujan). Studi dilaksanakan di pantai Warambadi, Pulau Sumba. Analisa t-test memperlihatkan bahwa "indeks keragaman jenis alga" ( $\left.\mathrm{H}^{\prime}\right)$ pada substrat laut berpasir dan berbatuan tidak memperlihatkan perbedaan yang signifikan. $\left(\mathrm{H}^{\prime}\right)$ pada musim kemarau dan hujan pada substrat yang berbeda tidak memperlihatkan perbedaan yang signifikan. Analisa two-way Anova memperlihatkan bahwa $\left(\mathrm{H}^{\prime}\right)$ dan jumlah jenis alga tidak terpengaruh oleh perbedaan substrat dan musim, akan tetapi terpengaruh secara signifikan oleh interaksi antara jenis subtrat dan jenis musim. Hasil studi mencatat pula bahwa jenis substrat dan musim berpengaruh terhadap $\left(\mathrm{H}^{\prime}\right)$ dari alga hijau tetapi tidak oleh interaksi keduanya. $\left(\mathrm{H}^{\prime}\right)$ dari alga merah terpengaruh oleh jenis substrat dan musim, tetapi tidak oleh interaksinya. Jenis substrat dan musim mempengaruhi $\left(\mathrm{H}^{\prime}\right)$ dari alga coklat, tapi interaksi jenis subtrat dan musim tidak berpengaruh terhadap $\left(\mathrm{H}^{\prime}\right)$. Fenomena substrat dan musim menunjukkan bahwa jenis substrat dan musim serta interaksinya berpengaruh terhadap jumlah jenis alga hijau, alga merah dan alga coklat.
\end{abstract}

Kata kunci: rumput laut, keragaman jenis, konservasi, substrat, musim 


\section{INTRODUCTION}

Seaweed is a marine algae and consists of classes Chlorophyceae (green algae), Rhodophyceae (red algae) and Phaeophyceae (brown algae). They live attached to the seabed between the top of the intertidal zone and the maximum depth to which adequate light for growth can penetrate. In general, there are internal and external factors that regulate seaweed growth and development. They interact with other marine organism and all interact with their physicochemical environment. Among the major environmental factors affecting seaweed growth are salinity, temperature, substratum, water motion, light, and nutrient availability ${ }^{(1,2,3)}$. Much seaweed adapts to changing climatic seasons through their life cycles, and the environment can cue their reproduction. In some of the morphologically less complex species, reproductive alternatives are determined by the environment. In others there is an obligatory cycle of generations cued by the seasons.

Seaweed is important component of tropical reef systems. The seaweed dominates the benthos of rocky shores, however, muddy and sandy shores have less seaweed since most species cannot anchor there (genera such as Halimeda and Caulerpa produce penetrating, root like holdfast). Seaweed usually grows vertically away from the substratum. This habit brings them closer to the light, enables them to grow large without extreme competition for space, and enables them to harvest nutrients from a greater volume of water.

The flora as seaweed changes from region to region. Just as terrestrial floras do, with each species having its own particular limits. In any given region the flora may comprise several distribution groups that extend various distances from polar or equatorial centers ${ }^{(4,5,6,7,8,9)}$. The factors that affect seaweed species distributions are physical factors and biological interaction. Among the physical factors potentially limiting seaweed distributions are substratum and salinity, which have important but localized influences, light and temperature.

The substratum factor, for example, influences the largely sandy shores and causes distinct discontinuities from the adjacent rocky shore floras ${ }^{(5)}$. The bases of coral reefs often abut sandy plains covered by seagrass or algae $^{(10,11,12)}$. Interactions occurring at the border or reefs and seagrass beds have been studied on several occasions, but little is known about those which occur between reefs and sandy shore dominated by algae ${ }^{(13,14,15)}$. Many seaweed species that occur on sand plains (sandy shore) require hard substrata such as shells and coral fragments ${ }^{(10)}$.
Temperature control of seaweed distributions comes from studies on tolerance of seaweed to extreme temperatures and from studies of temperature effects on algal life histories ${ }^{(5)}$. It indicates strongly that temperature effects on survival, growth, and reproduction are a primary cause of species distributions ${ }^{(5)}$. Temperature has quantitative effects on reproduction in a number of seaweed and qualitative effects on the life history. Most of the factors that affect the temperature of exposed rock pools also affect their salinity. Several of warmer water species also had a wider tolerance of salinity ${ }^{(16,17,18,19,)}$. In regions of extreme seasonal temperature change some seaweed species have life history events cued by temperature. Through the effects on life history and the temperature-range tolerances of seaweed, temperature affects the geographic distribution of seaweed and is probably the principal large-scale regulatory factor, substrata, salinity, wave action, and play important but local roles in phytogeography.

The purpose of this study is to evaluate the species diversity of seaweed with considered substrata (sandy and rocky shores) and seasonal change (rainy and dry seasons) and how to conserve species on the substrata.

\section{MATERIAL AND METHODS}

\subsection{Study Site}

The study was carried out on the Warambadi seashore of Sumba Island (Figure 1). In general, this area with a high degree of water movement, whether in the form of current or waves supported the growth of seaweed. Substrata is divided into rocky and sandy shores, and exposed substratum provides a range of excellent habitats for observing seaweed. The intertidal area of the observed site has variable environmental factors such as topography of the shoreline, type of rock, size of the wave and tidal fluctuation. These factors produce almost limitless different habitats for seaweed to colonize and thrive in. During low tide virtually all sandy area of the shore was exposed and about $20 \mathrm{~cm}$ to $40 \mathrm{~cm}$ seawater rising on rocky shore area. During the rainy season, Manangabodi River contributes fresh water that influence $\mathrm{pH}$ level and salinity

Dry season usually occur between April Nopember, and rainy season takes place between December - March. 


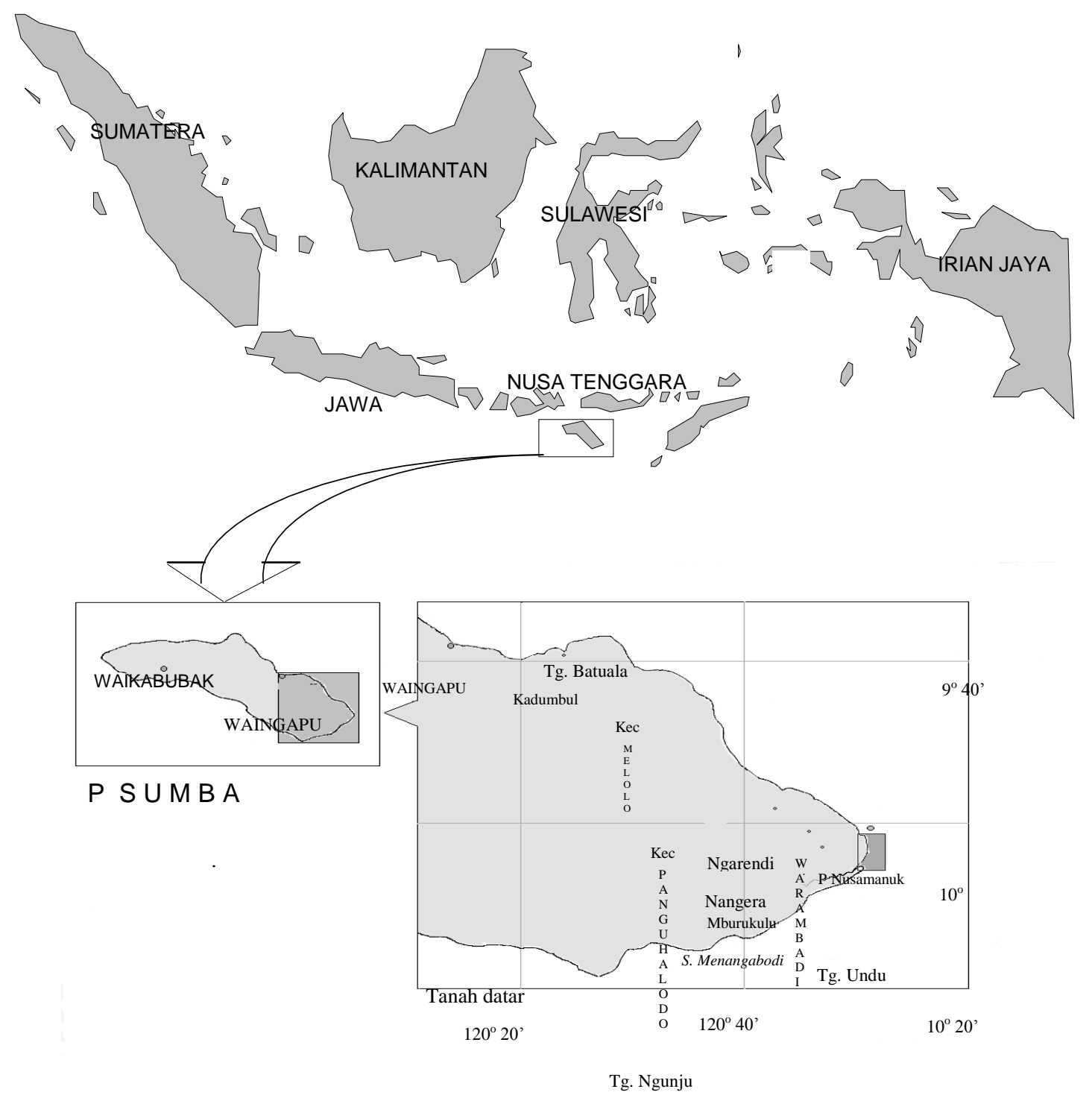

Figure 1. Study site

\subsection{Materials}

Seaweed were collected and preserved in 24 cc Formol (80\%), 1 cc Acetic acid glacial, $15 \mathrm{~g}$ $\mathrm{CuSO}_{4}$, distillation water was added to $1000 \mathrm{cc}$ volume.

\subsection{Methods}

Seaweed colonies were collected from five sampling units for each substratum. Each sampling unit covered an area of 100 square meters. The colonies were located randomly and represented both the sandy and rocky shore substrata. Every year, on July, the seaweed representatives of dry season with $0.1 \mathrm{~mm} R R$ (rainfall number), and on March, the seaweed representatives of rainy season with $149.8 \mathrm{~mm}$ $\mathrm{RR}$, in a month were collected by Meteorological and Geophysical Agency, 1996-1998 ${ }^{(20)}$. All collections were numbered by colony for each substratum and season. Identification of species according to Taylor ${ }^{(21)}$, Abbott and Norris ${ }^{(22)}$ Abbott $I A^{(23)}$ and Verheij and Prud'homme ${ }^{(24)}$.' According to season consideration, during the collection phase of seaweed, the $\mathrm{pH}$, salinity and temperature of seawater were also measured. The species diversity index $\left(H^{\prime}\right)$ was measured by using Magurran method with the basic formula from Shanon and Wienner ${ }^{(25)}$.

This study was intended to test : (1) effect of season on substratum differentiation and effect of substrata on seasonal differentiation by the "species diversity index" ( $H^{\prime}$ ) of total seaweed. (2) effect of substrata, seasons and their interaction on the $\left(H^{\prime}\right)$ of total seaweed and number of species. (3) effect of substrata, seasons and their interaction on the $\left(H^{\prime}\right)$ of each seaweed class i.e. Chlorophyceae, Rhodophyceae and Phaeophyceae. (4) effect of substrata, seasons and their interaction on the number of species of each seaweed class. To analyze these 
hypotheses was used t-test (two tailed) ${ }^{(26)}$ and two-way anova.

\section{RESULTS AND DISCUSSION}

\subsection{Results}

During the study, 23 genera including 79 species of seaweed grew in the study sites were collected. There were 9 genera of 37 species of green algae, 8 genera of 22 species of red algae, and 6 genera of 20 species the brown algae (Table 1, attached). The genera of green algae were Caulerpa, Chaetomorpha, Cladophoropsis, Codium, Dictyosphaeria, Halimeda, Microdictyon, Ulva, and Valonia. The species richness of green algae was covered by genera of Caulerpa and Halimeda, which showed the greater number of others. The species of the genera collected consisted of $59.4 \%$ of green algae or $27.8 \%$ of algae grew in such area. The genera of red algae were Acanthophora, Corallopsis, Eucheuma, Gracilaria, Hypnea, Kappaphycus, Laurencia and Meristotheca. The species of genera Eucheuma and Hypnea were the highest among the population of this class, and both genera were collected and covered $45.5 \%$ of red algae or $12.7 \%$ of the algae grew in the area. Ascophyllum, Dictyota, Hydroclathrus, Padina, Sargassum and Turbinaria were the genera of brown algae and Sargassum and Dictyota showed the majority of population. Table 1 also describes the number of colonies of species per sampling unit (S.U.) based on substrata and seasons. The water quality measurement showed the $\mathrm{pH}$, salinity and temperature during rainy and dry season as much as 7.6, 26.9 \% and $27.8{ }^{\circ} \mathrm{C}$, and $7.2,31.5 \%$ and $31.2{ }^{\circ} \mathrm{C}$, respectively.

Figure 2., describes the number of seaweed colonies per sampling unit based on both substrata and seasons. During the rainy season more colony of seaweed grow on sandy shore than on rocky shore substratum. On the contrary, more colony of seaweed grows on rocky shore than on sandy shore during the dry season
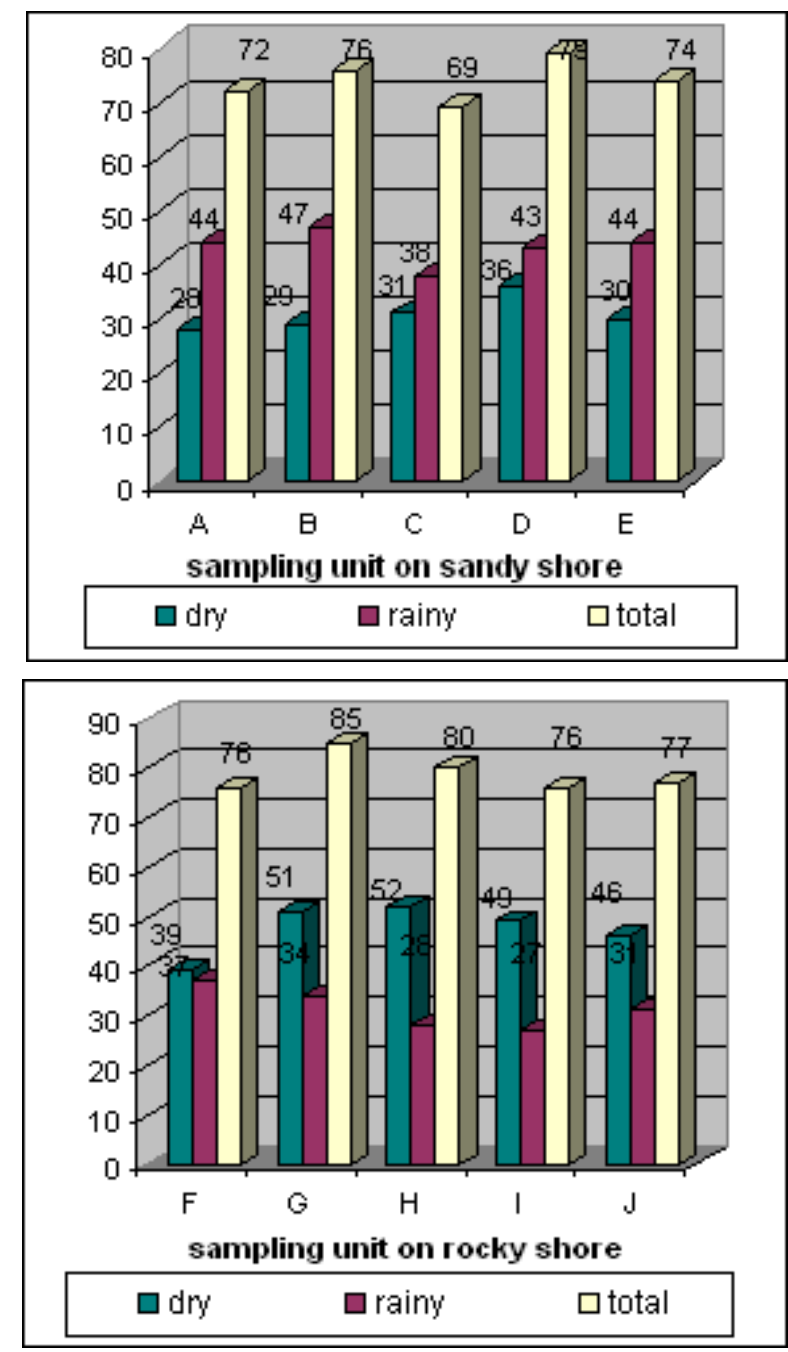

Figure 2. The number of seaweed colonies per sampling unit based on substrata and seasons.

Table 2. describes the number of species of three classes of seaweed per sampling unit based on substrata and seasons. Similarly to the number of colony of seaweed, during the rainy season more species growing on sandt shore than on rocky shore substratum. On the contrary, more species growing on rocky shore than on sandy shore during the dry season. Green algae mostly covered sandy shore substratum both during the rainy season as well as during the dry season. 
Table 2. The number of seaweed species of three classes per sampling unit based on substrata and seasons

\begin{tabular}{|c|c|c|c|c|c|c|c|c|c|}
\hline \multirow{3}{*}{ Season } & \multirow{3}{*}{ S.U } & \multicolumn{8}{|c|}{ SUBSTRATA } \\
\hline & & \multicolumn{4}{|c|}{ Sandy shore } & \multicolumn{4}{|c|}{ Rocky shore } \\
\hline & & Chloro & Rhodo & Phae & Total & Chloro & Rhodo & Phae & Total \\
\hline & $A$ & 20 & 12 & 5 & 37 & 13 & 11 & 9 & 33 \\
\hline & B & 22 & 9 & 3 & 34 & 8 & 8 & 11 & 27 \\
\hline \multirow[t]{4}{*}{ Rainy } & C & 23 & 10 & 2 & 35 & 12 & 6 & 6 & 24 \\
\hline & $D$ & 20 & 10 & 4 & 34 & 8 & 7 & 9 & 25 \\
\hline & $E$ & 22 & 11 & 4 & 37 & 9 & 10 & 12 & 31 \\
\hline & $E^{\prime}$ & 23 & 8 & 6 & 37 & & & & \\
\hline Total & & 130 & 60 & 24 & 214 & 50 & 42 & 47 & 140 \\
\hline \multirow[t]{3}{*}{ Averag } & & 21.7 & 10 & 4 & 35.7 & 10 & 8.4 & 9.4 & 28 \\
\hline & $\mathrm{F}$ & 12 & 9 & 4 & 25 & 7 & 13 & 13 & 33 \\
\hline & $G$ & 11 & 10 & 2 & 23 & 9 & 15 & 15 & 39 \\
\hline \multirow[t]{3}{*}{ Dry } & $\mathrm{H}$ & 13 & 9 & 7 & 29 & 9 & 18 & 15 & 42 \\
\hline & I & 14 & 10 & 7 & 31 & 8 & 16 & 15 & 39 \\
\hline & $J$ & 13 & 7 & 7 & 27 & 6 & 16 & 15 & 37 \\
\hline Total & & 63 & 45 & 27 & 135 & 39 & 78 & 73 & 190 \\
\hline Average & & 12.6 & 9 & 5.4 & 27 & 7.8 & 15.6 & 14.6 & 38 \\
\hline
\end{tabular}

Figure 3., describes the number of species of three seaweed classes that grew on different substrata and seasons. Species of green algae (Chlorophyceae) class mostly covered both on sandy shore and rocky shore substrata as well as during the rainy and dry seasons. Species of red algae (Rhodophyceae) and brown algae (Phaeophyceae) more growing during the dry season than the rainy season, and more growing on rocky shore than on sandy shore substratum.

Based on Table 2, was measured the species diversity index $\left(\mathrm{H}^{\prime}\right)$ of three classes of seaweed per sampling unit based on substrata and seasons by employed Magurran method with the basic formula from Shanon and Wienner (Table 3).
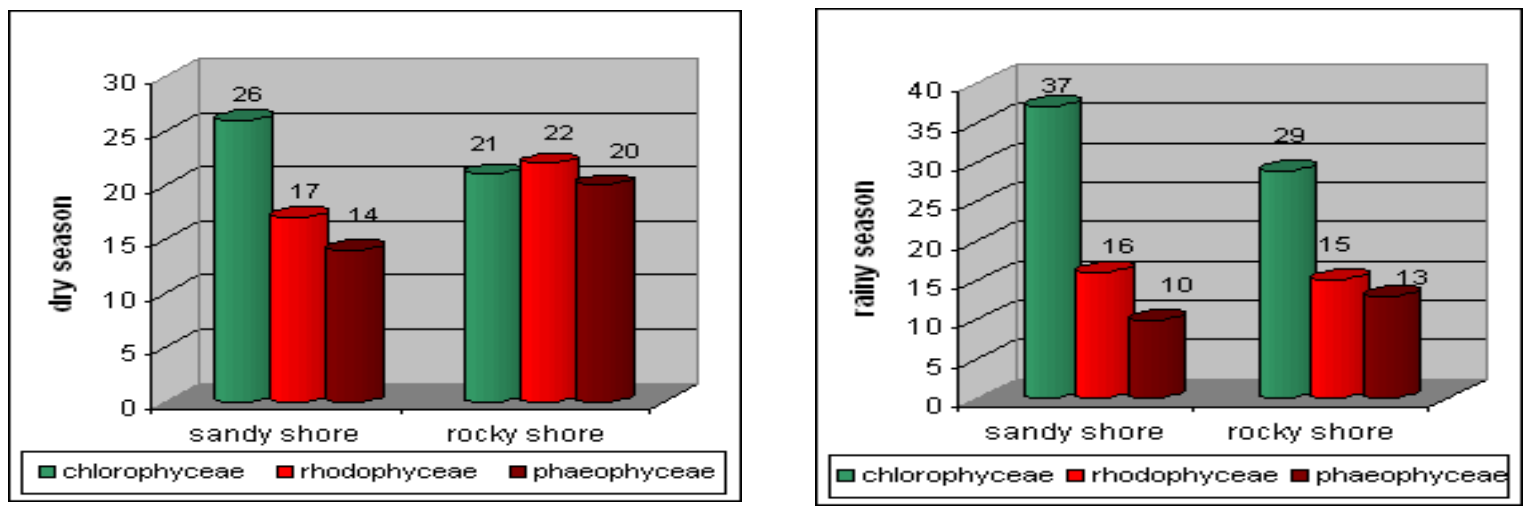

Figure 3. The number of seaweed species of three classes based on substrata and seasons. 
Table 3. Species diversity Index $\left(\mathrm{H}^{\prime}\right)$ of three classes based on substrata and season

\begin{tabular}{|c|c|c|c|c|c|c|c|c|c|}
\hline \multirow{3}{*}{ Season } & \multirow{3}{*}{ S.U } & \multicolumn{8}{|c|}{ SUBSTRATA } \\
\hline & & \multicolumn{4}{|c|}{ Sandy shore } & \multicolumn{4}{|c|}{ Rocky shore } \\
\hline & & Chloro & Rhodo & Phaeo & Total $^{x}$ & Chloro & Rhodo & Phaeo & Total $^{x}$ \\
\hline \multirow{6}{*}{ Rainy } & A & 1.2799 & 1.0557 & 0.6990 & 1.5477 & 1.1139 & 1.0290 & 0.8772 & 1.4894 \\
\hline & B & 1.2957 & 0.9319 & 0.4515 & 1.4911 & 0.9031 & 0.8565 & 1.0155 & 1.4008 \\
\hline & C & 1.3551 & 0.9788 & 0.3010 & 1.5323 & 1.0676 & 0.7526 & 0.7591 & 1.3611 \\
\hline & D & 1.2500 & 0.9788 & 0.6021 & 1.4916 & 0.9031 & 0.7967 & 0.9542 & 1.3561 \\
\hline & $E$ & 1.3206 & 1.0004 & 0.5786 & 1.5373 & 0.9542 & 1.0000 & 1.0792 & 1.4914 \\
\hline & $E^{\prime}$ & 1.3617 & 0.9031 & 0.7591 & 1.5639 & & & & \\
\hline \multirow{4}{*}{$\begin{array}{l}\text { Total } \\
\text { Average }\end{array}$} & & 7.8630 & 5.8487 & 3.3913 & 9.1639 & 4.9419 & 4.4350 & 4.6852 & 7.0988 \\
\hline & & 1.3105 & 0.9748 & 0.5652 & 1.5273 & 0.9884 & 0.8870 & 0.9370 & 1.4198 \\
\hline & $F$ & 1.0676 & 0.9319 & 0.6021 & 1.3827 & 0.8451 & 1.6958 & 1.0754 & 1.4926 \\
\hline & G & 1.0213 & 0.9750 & 0.2764 & 1.3378 & 0.9542 & 1.1392 & 1.1302 & 1.5225 \\
\hline \multirow[t]{3}{*}{ Dry } & $\mathrm{H}$ & 1.1031 & 0.9398 & 0.8451 & 1.4525 & 0.9542 & 1.2202 & 1.1520 & 1.5959 \\
\hline & 1 & 1.1242 & 0.9867 & 0.8278 & 1.4727 & 0.9031 & 1.1679 & 1.1400 & 1.5581 \\
\hline & $\mathrm{J}$ & 1.1031 & 0.8205 & 0.8451 & 1.4169 & 0.7782 & 1.1679 & 1.1549 & 1.5400 \\
\hline Total & & 5.4193 & 4.6539 & 3.3965 & 7.0626 & 4.4348 & 6.3910 & 5.6525 & 7.7091 \\
\hline Average & & 1.0839 & 0.9308 & 0.6793 & 1.4125 & 0.8870 & 1.2782 & 1.1305 & 1.5418 \\
\hline
\end{tabular}
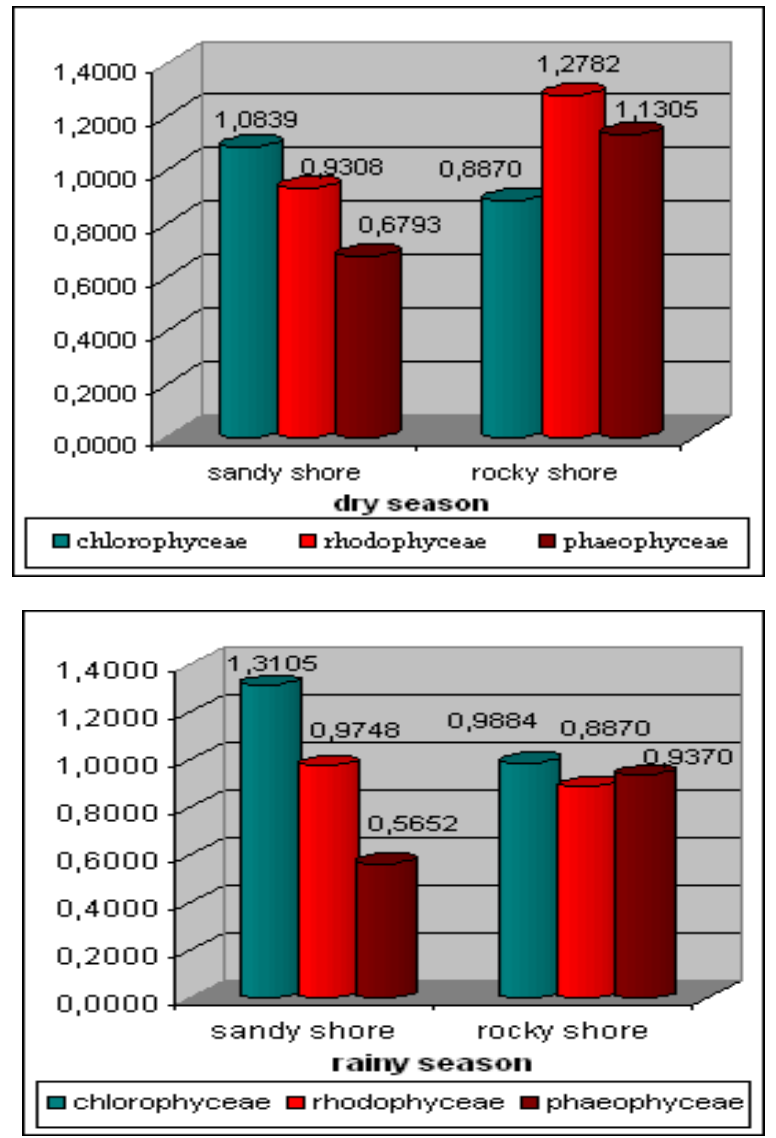

Figure 4. The average of species diversity index $\left(\mathrm{H}^{\prime}\right)$ of three classes based on substrata and Seasons.

Figure 4 exhibits the average of species diversity index $\left(\mathrm{H}^{\prime}\right)$ of three classes of seaweed based on substrata and seasons.
During the rainy season, the highest diversity index is green algae on sandy shore, and during the dry season the highest diversity index is red algae on rocky shore followed by brown algae on the same substratum.

\subsection{Discussion}

Several species of green algae can not grow in high salinity and high temperature. As the consequence of this particular circumstances, eleven species of green algae were not able to grow completely during the dry season. They were Caulerpa racemosa $v$. macrophysa, C. racemosa $v$ laetevirens, $C$. racemosa $v$. uvifera, C. taxifolia, Codium fragile, Halimeda gracilis, and $H$. simulans, $H$. tuna, Microdictyon japonicum, Valonia macrophysa, and $V$. utricularis, $V$. ventricosa. On the contrary, several species of red algae and brown algae can not grow in the lower salinity and temperature, and, consequently, six species of red algae and seven species of brown algae were not able to grow during the rainy season. They were Eucheuma isiforme, Hypnea chordacea, H. pannosa, Laurencia cartilaginea, L. mariannensis and Meristotheca papulosa of red algae, and Ascophyllum sp., Dictyota bartayresii, $D$. crenulata, Sargassum echinocarpum, $S$. hemiphyllum, Turbinaria conoides and $T$. decurens of brown algae. In such a case, Manangabodi River plays important role in lowering water salinity of the area by contributing fresh water during rainy season (Table 1 ).

Temperature is undoubtedly the most fundamental factor for all organism due to its 
effects on molecular activities and properties, and hence on virtually all aspects of metabolism. Living organism were rarely at thermal equilibrium with their environment ${ }^{(27)}$. However, the internal temperatures of seaweed and other poikilothermic organism were usually near the temperature of their surfaces or of the surrounding air or water ${ }^{(28)}$. In addition, seasonal change also affected temperature and salinity of ocean water.

The Figure 4 and Table 2 indicate that the sandy shore is mostly covered by green algae, and in addition, Caulerpa and Halimeda genera are apparently the richness species of green algae on sandy shore. They have holdfast or similar roots to anchor their body on sandy shore, and several species were attached on shells or coral fragments. On rocky shore and during dry season, the species richness was red and brown algae. Many species of red and brown algae naturally preferred hard substrata for growing and many of them were not tolerance to lower water salinity such as Eucheuma isiforme, Hypnea chordacea, Laurencia cartilaginea, and Meristotheca papulosa of red algae, and Ascophyllum sp., Dictyota bartayresii, Sargassum echinocarpum, S. hemiphyllum, Turbinaria conoides and $T$. decurens of brown algae. On the other side, the populace of green algae was the highest on rocky shore. This phenomenon was probably caused by the species preference to grow and with attach themselves on hard substrata. Seawater movement as the further effects of waves or the current of Manangabody River during the rainy season also affected several species.

\section{Species diversity index $\left(H^{\prime}\right)$ per substratum and per season}

The $t$-test analysis was conducted to answer questions on: (1) The possible differentiation of species diversity index ( $\left.H^{\prime}\right)$ of total seaweed which grow (in all sampling units) on sandy and rocky substrata during rainy and dry seasons; (2) The possible differentiation of species diversity index of total seaweed which grow (in all sampling units) during rainy and dry seasons on sandy and rocky substrata. The results of the $t$ test showed that virtually all $t_{\text {cal }}$ whether between substrata during the same season, or between seasons on the same substratum showed lower value than the $t_{\text {tab }}(+)$ or higher than the $t_{\text {tab }}(-)$ at $p 0.05$ and $p 0.01$.

According to the working hypotheses, this finding significantly showed that; (1) the species diversity index of algae on both sandy and rocky substrata during dry and rainy seasons did not significantly different, and (2) the species diversity index of algae during both rainy and dry seasons on different substratum did not show any significant differences. The above condition turned out due to the balance of species growing during both seasons and both substrata (Figure 3 and 4). Several species of seaweed did grow during the rainy season but they did not grow during the dry season. Eleven species of green algae that grew during rainy season, but did not grow at all during dry season. On the contrary, six species of red algae and seven species of brown algae grew during the dry season but not able to grow during the wet season. In relation to substratum, although almost all green algae grew in the sandy shore, more than $50 \%$ green algae grew in the rocky shore. By contrast, although red and brown algae preferred to grow on the rocky shore, some species also grew in the sandy shore such as Eucheuma, Hypnea and Laurencia of red algae and Dictyota, as well as several Sargassum of brown algae (Table 1).

\section{Effects of substrata and seasons on species diversity index $\left(H^{\prime}\right)$ and total species}

This analysis was intended to answer the question on whether substratum and season and their interaction affected the species diversity index of total seaweed (in all of sampling units) and to the number of species. The results of the analysis showed that the species diversity and the number of algae species were not affected by the differences of both substrata and seasons, but it was significantly affected by interaction between the types of substratum and season.

Interaction between substratum and season probably occur due to the seasonal change, which affected temperature, salinity and irradiation. These circumstances further affected the substratum condition. The seasonal change also influenced the change on the surface of the substratum, for example, the effect of mud brought by the waves of Manangabodi River during the rainy season.

\section{Effects of substratum and season on species diversity index $\left(H^{\prime}\right)$ and total species per classes of seaweed}

This analysis answered the questions on whether substratum, season, and their interaction affected to the species diversity index of each seaweed classes (Chlorophyceae, Rhodophyceae and Phaeophyceae), and on whether substratum, season, and their interaction affected the number of species of each seaweed class.

\section{A. Species diversity index}

The result of the analysis showed that; (1) the species diversity of Chlorophyceae and Phaeophyceae was affected by the types of substratum and season, but not by their 
interaction, and (2) the species diversity of Rhodophyceae was affected by seasonal change and interaction between the types of sunstratum and season, but not by the types of substratum.

The green algae preferred to grow on sandy shore and many green algae species were more tolerance to lower salinity and some did not tolerate higher salinity. The seasonal change normally affected these two properties and, therefore, seasonal change significantly affected the species diversity index of green algae. The species of red algae was less tolerant to salinity and temperature changes due to seasonal change. Much of this species were able to grow on both sandy and rocky substrata.

Naturally, brown algae were not tolerant to changes of salinity and types of substratum. Most brown algae grew well in high salinity and posses benthic properties so they were able to adapt to rocky environment. If they grew on sandy shore, they attached to hard substratum such as shells or coral fragments washed ashore by ocean waves or currents.

\section{B. Number of species}

The result of the analysis showed that types of substratum, season, and their interactions affected the number of species Chlorophyceae, Rhodophyceae, and Phaeophyceae.

Green algae species preferred to grow on sandy shore than on rocky areas. Many of also were able to tolerate lower salinity. Some specific species of red algae were able to grow on either sandy or rocky area, and some were able to grow on both substrata. Salinity and temperature changes as affected by seasonal change significantly influenced the growth of several species of red and brown algae. Furthermore, the interactions between types of substratum and season also affected the growth of green, red and brown algae species.

\section{CONCLUSION}

The general conclusion drawn from the results was that substratum and season play important roles in species diversity index of algae species. The interaction of these variables also contributed to such diversity index of algae species in the study area as well as to the number of the species. The Chlorophyceae and Phaeophyceae showed positive response to types of substratum and seasonal change, but not to their interactions. But, the Rhodophyceae showed positive response to seasonal change and interaction between the types of substratum and seasonal change, but not response to types of substratum. Types of substratum, season, and their interactions affected the number of species Chlorophyceae, Rhodophyceae, and Phaeophyceae.
Species conservation should be based on the interaction between species and substrata, the interaction between species and seasons, and species response to the interaction between substrata and seasons. Species wild crops management should be based on species diversity index and total species.

\section{ACKNOWLEDGMENTS}

I would like to express my deepest gratitude to Professor Dr. Mien A. Rifai for his continuous direction to explore knowledge through scientific approaches. Special thanks goes to $\mathrm{Mr}$. Johannes Sukantyo MBA., the CEO of PT Sumba Subur in Surabaya for his support during activity in Warambadi seashore and to Mr. Effendy Tjoeng, President Director of PT Agarindo Bogatama for his support in this study. I thank who helped weed, maintain, census the plots, and identification, including Wisnu Sudjatmiko, APi., Wisman Indra Angkasa, APi., Anis. I also thank Drs. Wisnu Wardhana MSi. for contribution to statistical analyses.

\section{BIBLIOGRAPHY}

1. Christoper, S.L., P.J. Harrison, and M.J. Duncan, (1985), The physiological ecology of seaweeds, Cambridge, Cambridge U.P.

2. Jon D. Witman, W.L. Robert W, and E.K. Jarrett Byrnes, (2015), Towards an integrationof scale and complexity in marine ecology, Ecological Monographs, 85: 4, 475.

3. Muller, R., T. Laepple, I. Bartsch, and C. Wienck, (2009), Impact of oceanic warning on the distribution of seaweeds in polar and colstemperate waters, Botanica Marina, 52:617638.

4. Druehl, L.D., J.M. Green, (1982), Vertical distribution of intertidal seaweeds as related to patterns of submersion and emersion, Mar. Ecol. Progr. Ser., 9: 163 -170.

5. Van den Hock. C., (1982), Phytogeographic distribution group of benthic marine algae in the North Atlantic Ocean. A review of experimental evidence from the life-history studies, Helgol. Meeresunters, 35: 153-214.

6. Matthew, E.S. Bracken, and L. Susan Williams, (2013), Realistic changes in seaweed biodiversity affect multiple ecosystem, Ecology, 94(9), pp. 1944-1954.

7. Gustafsson, C. and C. Bostrom, (2011), Biodiversity influences ecosystem functioning in aquatic angiosperm communities, Oikos 120: 1037-1046. 
8. Wiencke, C. and M. Clayton, (2009), Biology polar benthic algae, Botanica Marina, 52: 479481.

9. Wiencke, C., I. Gomez, and K. Dunton, (2009), Phenology and seasonal physiological performance of polar seaweeds, Botanica Marina, 52: 585-592.

10.Dahl, A.L., (1973), Benthic algal ecology in a deep reef and sand habitat of Puerto Rico, Bot. Mar., 16: 171-175.

11.Wuff, A., K. Iken, M.L. Quartino, A. Al-Handal, C. Wiencke, and M. Clayton, (2009), Biodiversity, ciogeography and zonation of marine benthic micro- and macroalgae in the Antartic, Botanica Marina, 52: 491-507.

12.Stachowicz, J.J., M. Graham, M.E.S. Braken, and A.I. Szoboszlai, (2008), Diversity enhances cover and stability of seaweed assemblages: the role of heterogeneity and time, Ecology, 89: 3008-3019.

13.Ogden, J.C., (1976), Some aspects of herbivore-plant relationships on Caribbean reefs and sea grass beds, Aqua. Bot., 2:103116.

14.Hay, M.E., (1981), Herbivory, algal distribution, and the maintenance of betweenhabitat diversity on a tropical fringing reef, Am. Nat., 118: 520-540.

15. Scherber, C., N. Eisenhauer, W.W. Weisser, and Schmid, (2010), Bottom-up effects of plant diversity on multitrophic interactions in a biodiversity experiment, Nature, 468: 553-556.

16.Dring, M.J., (1974), Reproduction. In: Stewart WDP (eds), Algal Physiology and Biochemistry, Blackwell Scientific Publication, Oxford, (pp 814-837)

17.Fralick, R.A., and A.C. Mathieson, (1975), Physiological ecology of four Polysiphonia species (Rhodophyta, Ceramiales), Mar. Biol., 29: 29-36.

18.Luning, K., (1980), Control of algal life-history by day length and temperature. In: Price, J.H., D.E.G. Irvine, and W.F. Farnham, (eds), The Shore Environment, Vol. 2. Ecosystem, Academic Press New York, (pp. 915 - 945)

19.Nybaken, J.W., (1992), Biologi laut: Suatu pendekatan ekologis, Gramedia, Jakarta.

20.Meteorological and Geophysical Agency, (1996-1998), Annual and Monthly Report of Rainfall Data, Jakarta, BMKG.

21.Taylor, W.R., (1960), Marine algae of the eastern tropical and subtropical coast of the Americas, The University of Michigan Press.
22.Abbott, I.A., and J.N. Norris, (1985), Taxonomy of economic seaweeds: with reference to some Pacific and Caribbean species, California Sea Grant College Program, Report No. T-CSGC-011.

23.Abbott, I.A., (1986), Taxonomy of economic seaweeds: with reference to some Pacific and Caribbean species, California Sea Grant College Program, Report No. T-CSGC-018.

24. Verheij, E., W.F. Prud'homme van Reine, (1993), Seaweeds of the Spermonde Archipelago SW Sulawesi Indonesia, Blumea, 37: 385-510.

25.Magurran, A.E., (1988), Ecological diversity and its measurement, New Jersey, Princenton U. P.

26. Brower, J.E., J.H. Zar, C.N. von Ende, (1989), Field and laboratory methods for general ecology, $3^{\text {rd }}$. ed. Wm. C. Brown Publ., Dubuque.

27.Campbell, G.S., (1977), An Introduction to environmental bio-physics, New York, Springer-Verlag.

28. Forstner, M., and K. Rutzler, (1970), Measurements of the microclimate in littoral marine habitats, Oceanogr. Mar. Bio. Ann. Rev. 8: 225-249. 


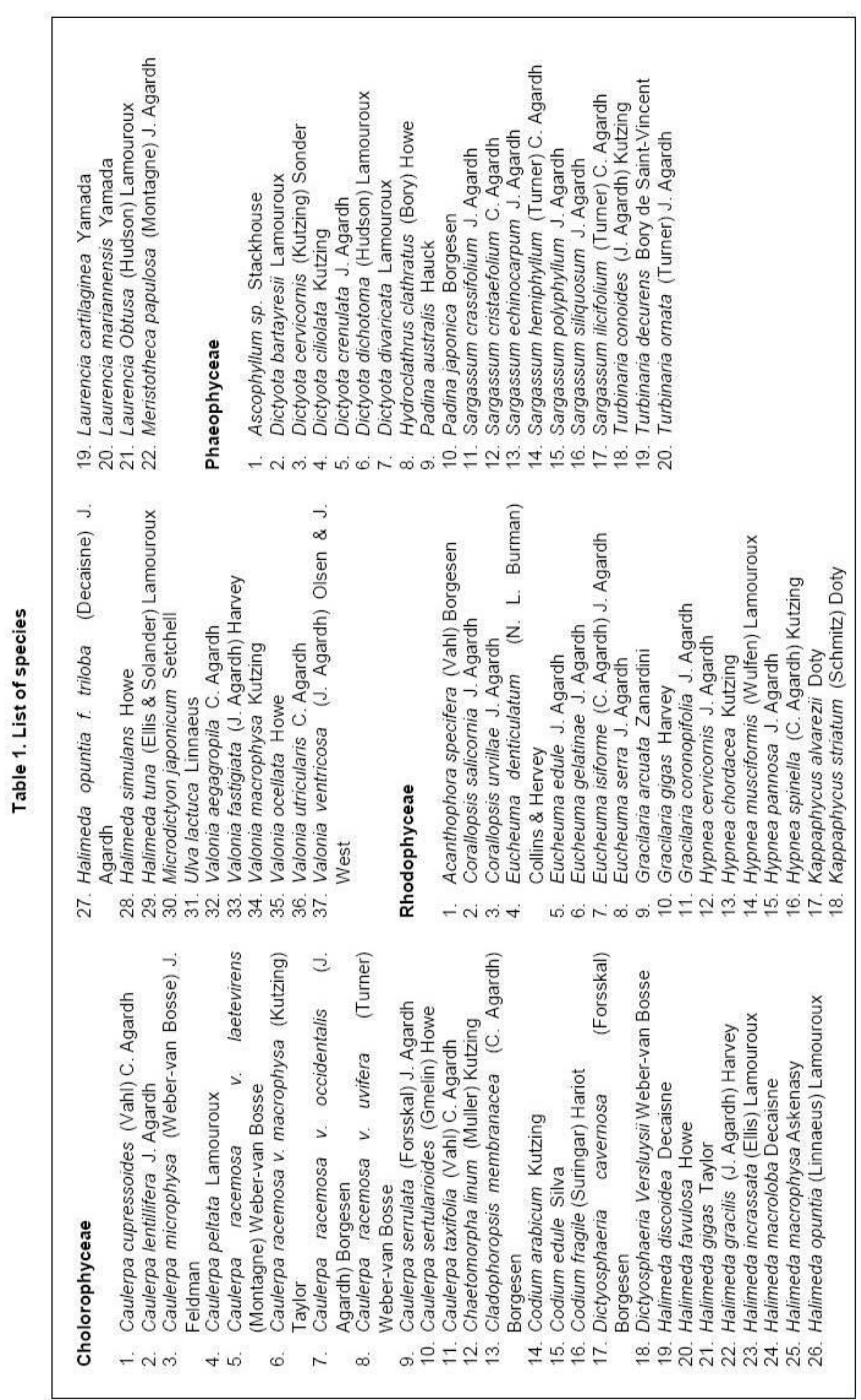

